\title{
Ecosystem services in cities: towards the international legal protection of ecosystem services in urban environments
}

\author{
Authors: Aysegül Sirakaya (PhD Researcher, Ghent University), An Cliquet (Associate Professor, \\ Ghent University), Jim Harris (Professor, Cranfield University)
}

Corresponding Author: Aysegül Sirakaya, PhD Researcher at Ghent University

E-mail : aysegul.sirakaya@ugent.be

Address: Ghent University, Faculty of Law, Department of International and European Law, Universiteitstraat 4, 9000 Ghent/Belgium

Keywords: international biodiversity law; urbanization; biodiversity; ecosystem services; conservation; restoration

\begin{abstract}
Biodiversity provides many ecosystem services in cities that are beneficial to human well-being including adaptation to the effects of climate change and positive effects of nature on human health. Rapid urbanization however is causing an adverse impact on biodiversity and the ecosystem services they provide. Protecting and restoring urban biodiversity and ecosystem services can increase human well-being of the rapidly increasing urban population. Today, however, the international biodiversity conservation practice mainly focuses on rural areas, and not on urban conservation and restoration. Within city scale, there are several opportunities to green urban living, such as green infrastructure and urban parks and nature reserves. This paper investigates the current scientific practices for promoting and protecting ecosystem services in urban areas. Secondly, the authors review and assess the legally binding instruments on biodiversity at international and EU level in order to see if there are sufficient existing mechanisms for protection of ecosystem services in urban areas. Thirdly, the paper elaborates on the Aichi Targets in order to explore whether or not these targets are enough to facilitate the protection and enhancement of ecosystem services in urban areas as swiftly as they are needed.
\end{abstract}

Highlights

- Protection and restoration of biodiversity in cities is key to providing ecosystem services in an increasing urbanized world.

- In recent years, international environmental law has recognized the important role that cities play in protecting biodiversity and providing ecosystem services.

- Technical guidance that focuses on the solutions for challenges of implementation of urban ecosystem restoration, is lacking at the international level.

- Legally binding requirements for international targets -rather than voluntary schemes at the national level- are vital for addressing urban challenges related to ecosystem services coherently and progressively. 
Biodiversity in cities can provide many ecosystem services beneficial to human well-being and human health. Rapid urbanization creates both challenges and opportunities for biodiversity and ecosystem services. Conserving and restoring biodiversity in cities is a key element for reaching sustainability goals and can help reverse the ongoing biodiversity crisis. This paper examines the international legal and policy framework for the protection of biodiversity and ecosystem services in cities. The paper first analyses why biodiversity and ecosystem services in urban environments are so important, and why they should be conserved or restored (section 2). The protection of urban biodiversity and ecosystem services is situated at multilevel scales and includes legal and policy commitments ranging from the international global, regional, national to a local city level. This paper will focus on international global commitments and will briefly mention some international regional examples as well. Rapid urbanization and the impact it has on biodiversity is a worldwide concern, and although the answers to solving this challenge can have regional and local differences, global commitments are the main starting point. In general, urban ecosystems are not explicitly excluded from international legal binding documents. In recent years they have become a focus of attention in several non-binding soft law documents, such as the decisions from the Conference of Parties (COP) to the Convention on Biodiversity and other multilateral or regional environmental agreements. Section 3 will examine the legal commitments under the Convention on Biodiversity and the Ramsar Convention. It will also briefly look into two regional examples, namely the European Bern Convention and EU law. Section 4 of this paper will examine the Aichi Targets to the Biodiversity Convention with regards to their relevance to urban nature conservation and restoration. Specifically, the paper will elaborate on Targets 14 and 15 in relation to urban biodiversity and ecosystem services, and provide the results of an analysis of the national biodiversity strategy and action plans (NBSAP) under the Convention, specifically relating to urban biodiversity.

\section{The importance of urban biodiversity and urban ecosystem services}

Biological organisms are the central agents in the functioning of ecosystems, and the diversity of these organisms (biodiversity hereafter) has profound influence of this function (Hooper et al., 2005). This biodiversity, along with the stocks of abiotic materials and their disposition and interactions are known as "Natural Capital", which is dependent on biodiversity (Balvanera et al., 2006) and delivers human well-being (Millennium Ecosystem Assessment, 2005). There are several compelling reasons for preserving and restoring biodiversity which go beyond simple utility (Pearson, 2016) and continuing losses will have adverse effect on ecosystem function and therefore degrade ecosystem service flows (Cardinale et al., 2012).

Urban areas are usually developed in areas of high biodiversity, as humans tend to establish settlements around where most natural resources are (Cincotta et al., 2000; Luck, 2007; Macdonald et al., 2008) and consequently management for the conservation of biodiversity, especially with regards to expansion and new developments (e.g. Pauchard et al., 2006) is crucial if we are to avoid further biodiversity loss (McKinney, 2006) as well as increased effects of climate change in urban areas. Urbanization is a major cause of biotic loss and homogenisation, maintained for centuries in a state by suppression of natural processes. The import of non-native species can replace native flora and fauna, which is particularly acute if the species are invasive (McKinney, 2006). However, urban species are very often abundant and diverse - allowing for effective conservation and restoration interventions. The current world urbanization prospects stipulate that $66 \%$ of the global population will live in cities by 2030 (UN, 2014). Continuing rapid urbanization will be a major challenge to 
protected areas and biodiversity conservation, and require thoughtful planning, monitoring and regulation (Mcdonald et al., 2008; Haaland et al., 2015). Even those cities with an explicit "Green" agenda in their planning regulations have struggled to maintain green to built infrastructure ratios with appropriate character and fragment sizes (e.g. Tan et al., 2013). This is important as green infrastructure is where most of the Natural Capital of urban areas is to be found, in terms of the primary producers (plants) upon which ecosystem function is based. It is from this that the principal "ecosystem services" are derived - supporting, regulating, provisioning, and cultural. The situation in urban areas is complex as, for example, tall buildings can provide nesting sites for top level predators (e.g. peregrine falcons) and built structures can provide regulation services (e.g. flood control). Also, there are urban areas where there are large "hybrid" urban-rural components (e.g. European Parliamentary Research Service, 2016). It has been suggested that there is a distinct biogeochemistry (Kaye et al., 2006) and that there are complex mixes of the natural-unnatural spectrum dependant on each cities' layout. Clearly, the natural components of urban areas, delivered by biodiversity, can provide ecosystem services in situ, such as carbon sequestration, flood mitigation, aesthetic pleasure and pollination. Ziter (2016) has reviewed the role of biodiversity in delivering ecosystem services in urban areas and has found that most studies have focussed on the relationship between biodiversity and regulating services - which were found to be dependent on composition of species, functional groups, or their inter-relationships in communities.

Nature can play a significant role in maximising the benefits and minimising the negative effects of urban living, and the Natural Capital-ecosystem services framework has provided a basis for understanding these benefits and has been used to inform decisions as to which policy options (e.g. urban planning, green infrastructure) might maximise well-being outcomes (e.g. Salmond et al, 2016), and increase resilience to environmental risks (e.g. Kabisch et al, 2016). Nature and biodiversity in cities provide numerous ecosystem services (Szlavecz et al., 2011). Stimulating or restoring ecosystem services in cities can be effective solutions for both climate change adaptation and mitigation (Dover, 2015; European Commission, 2015). Urban ecosystem services do this by providing cool air to cities which leads to reduction in energy consumption particularly in the summer. Restoring local wetlands can result in the prevention of disease and natural disaster to a great extent (SCBD, 2012). Urban ecosystem services improve the air and water quality and thus provide a more resilient urban living to locals. Urban ecosystem services can also improve the social inclusion in a city and provide public space for activities and leisure (Millennium Ecosystem Assessment, 2005). Chiesura (2004) identified the crucial role that urban parks play in securing sustainability, through both direct biophysical links to health, and to psychological well-being through exposure to nature (e.g. Shanahan et al., 2015; Soga et al., 2015). In a recent systematic review, van den Berg and colleagues (2015) demonstrated strong evidence for significant positive associations between the quantity of greenspace and perceived mental health and all-cause mortality, and moderate evidence for an association with perceived general health. Haase and coworkers (2014) have carried out a quantitative review of how ecosystem services are assessed in urban areas. They conclude that although a wide range of approaches have been taken, covering many studies including biophysical models, geographical information systems (GIS), and valuation, there is little evidence that there has been significant take up in land use policy.

The empirical evidence for this and the wider benefits of urban nature has been steadily accruing in recent years and a clearer picture is emerging as to not only the importance of individual elements of Natural Capital but also how the integration, feedbacks and interdependencies of the grey-greenblue infrastructure of our urban areas are essential for securing sustainability. Certainly, it has been possible to demonstrate that the presence of "natural" features (such as trees, hollow and decaying logs, ground and mid-storey vegetation) are beneficial and their loss leads to degradation of wellbeing (Le Roux et al., 2014). Urban habitats may contain, in addition to alien species, many endemic, rare and endangered species but in pockets of refugia disconnected from the wider landscape. Still there are opportunities for providing ecosystem service and biodiversity benefits beyond the city (Kowarik, 2011). In particular, large old trees need special protection in urban areas, as single 
specimens in isolation, but also as part of parks and reserves (Lindenmayer, 2014). There are many active research programmes aimed at mapping the ecosystem services arising from these interactions, and the models being produced are increasingly accurate at mapping multiple services (e.g. Grafius et al., 2016): this is essential if decision making at the scale of the level of the street and household are to be made (Gret-Regamey et al., 2015).

There are undoubtedly challenges to securing and enhancing urban ecosystem services, which have been clearly outlined by Luederitz et al. (2015). These are:

1. Comprehensive spatial and contextual coverage of research - most work is currently concentrated in the developed countries of the northern hemisphere, whereas some of the most acute problems of rapid urbanization occur in Low and Middle Income Countries (LMICs), with tropical climates, and very different natural ecosystem starting points. Often studies also give no population size/area context, making transferability and generalisation difficult or impossible.

2. Clarification of definitions - particularly around the definition of "urban" which requires unambiguous description of the environmental, spatial and socio-economic context. This includes the problem of "city limits" - you can have a large "green city" by extending the city limits to include "natural" areas, but with no benefits for urban dwellers at the core.

3. Limited transferability of data - global estimates of services and values cannot easily be transferred to local contexts, due to differences in biomes and socio-economic circumstances.

4. Stakeholder engagement - few studies involve stakeholders $(20 \%$ or fewer according to Luederitz et al.'s findings), leading to the danger that the process could become technocratic, and there is an urgent need for engaging stakeholders in ecosystem service research.

5. Integrated research effort - there is a need for trans-disciplinarity in the research effort, otherwise it will be impossible to capture the full diversity and richness of ecosystem service provision by green infrastructure (Potschin and Haines-Young, 2011).

6. Closing the feedback loop between urban ecosystem service appropriation and the management of urban ecological structures - research and assessment has to be properly connected to the management of urban ecological components within the green infrastructure, and the management regimes, actors and regulations. Without this there is little prospect of translating research findings into action on the ground.

These gaps are legion, but offer rich opportunities for understanding within and between disciplines in many fields - and a solid agenda for providing impact in real lives in the places where most people live.

Conservation and restoration of Natural Capital, and therefore ecosystem services flowing from it, in urban areas can reduce their ecological footprints and enhance resilience, health and the quality of life of inhabitants - and these values can be captured by a variety of means (Gomez-Baggethan and Barton, 2013; Shaffler and Swilling, 2013). This requires a blend of socio-economic and ecological analysis and understanding, synthesised as a result of open and frank trans-disciplinary work. It is therefore logical that, by investing in green infrastructure and Natural Capital, we should improve ecosystem services flows and positive well-being outcomes. Elmqvist and co-workers (2015) have demonstrated that investing in the ecological infrastructure in the USA, Canada and China, has resulted in monetary benefits, in addition to the already recognised ecologically and socially desirable improvements. Protecting and restoring urban biodiversity and Natural Capital has to be taken into the public planning, legislative and regulatory regime. The next sections will examine whether international law and policy provides an adequate legal basis to do so. 


\section{Legal obligations for protecting and restoring urban ecosystem services}

\subsection{Legal obligations at multilevel scales}

Although many cities are already taking initiatives to protect or restore urban ecosystem services (e.g. SCBD, 2012), much more can and needs to be done, in light of the ongoing biodiversity crisis and urban sprawl and the interlinkages between both. The national or local legal framework, including zoning and planning legislation, biodiversity legislation and environmental legislation in general can all play an important role in facilitating and regulating the protection and enhancement of urban ecosystem services. Berlin's biotope mapping which started in the 1970s in order to map the biodiversity richness in the city is a good example of an enhanced national effort. This effort later turned into a legally binding planning arrangement called "Biotope Area Factor". The Biotope Area Factor aims to protect nature in the areas of development by establishing requirements on the percentage of green on and around buildings (http://www.stadtentwicklung.berlin.de/). Another example is Japan's 43-year-old Urban Green Space Conservation Act which aims to conserve, restore and create green spaces which provide precious ecosystem services by designating special green conservation areas (https://www.cbd.int/doc/world/jp/ip-nr-05-en.pdf). Some countries' laws such as Finland's does include urban conservation areas in general planning acts or conservation laws and do not regulate urban biodiversity separately (https://www.cbd.int/doc/world/fi/fi-nr-05-en.pdf).

National laws are however beyond the scope of this article. This paper will focus on the international legal framework. International law can provide the necessary impetus that States need in order to take the required measures to protect and enhance urban ecosystem services. Young (2011) argues that international environmental commitments such as in regulatory settings help to a great extent create willingness amongst Parties to act as prescribed. In other words, international governance often ends up strengthening commitments at the national level. Since urban biodiversity protection is a novel topic within the legal doctrine, it is therefore worthwhile to explore the attention that is given at the international level to urban biodiversity and ecosystem services, as this can be an illustration of the growing political willingness to tackle these issues, and can even amount to legally binding norms, at various geographical scales. Environmental law in general is often a complex mixture of international, regional hard and soft law, further implemented into national policies and laws. From a formal point of view, a distinction is made between hard law, in the form of binding international or regional conventions, and soft law, such as non-binding COP-decisions. It would be too simple to categorize the formal soft law instruments, such as most COP-decisions, as legally nonbinding, and thus having no or little legal effect. Both international hard and soft law can influence laws and policies at the regional and national level. COP-decisions can also be used as an interpretation of hard law obligations in a convention (Verschuuren, 2008). Not only the form of the document is important in this regard, but also the language used (obligatory or stimulating), as well as implementation mechanisms (ranging from judicial mechanisms to reporting to international bodies). In the following sections the current legal obligations in international law will be examined. A subsequent section 4 will look at concrete targets that have been set in international environmental law. The focus will be on the protection and restoration of biodiversity in cities, as ecosystem services depend on well-functioning ecosystems and biodiversity, as was pointed out in the section 2. As such, international law on - for example - water pollution or air pollution will not be dealt with, although undoubtedly these legal instruments can contribute to the protection of urban ecosystem services.

The instruments that are examined are limited to the Convention on Biological Diversity (CBD, 1992), and the Ramsar Convention (1971) and the subsequent decisions by the Conference of Parties (COP). 
At the regional level, both the Bern Convention (1979) and the EU nature legislation will be briefly explored. Although the focus of many international biodiversity conventions is predominantly aimed at the protection of the rural environment, it as such does not exclude the protection of biodiversity in cities.

\subsection{Biodiversity Convention}

The Biodiversity Convention in its Article 2 defines "biological diversity" as "the variability among living organisms from all sources including, inter alia, terrestrial, marine and other aquatic ecosystems and the ecological complexes of which they are part; this includes diversity within species, between species and of ecosystems." Although urban biodiversity is not mentioned explicitly, the definition does not exclude it. As a consequence, the legal obligations of the Convention, such as those provided in Article 8 on in situ conservation also apply to urban ecosystems and biodiversity. However, it is only in recent years that explicit attention has been paid to urban biodiversity. The role of cities in the implementation of the Convention is increasingly recognized and from 2008 onwards, every COP meeting has paid some attention to the role of cities. Cities are now seen as a major group and "the Parties to the CBD are increasingly seeking to engage with subnational governments to accelerate and improve implementation of the Convention." (https://www.cbd.int/subnational). In several COP decisions, attention has been paid to the role of cities in the protection of biodiversity and ecosystem services. While the responsibilities for implementation of the Convention rest primarily with the State Parties, the engagement of cities is recognized. State Parties are therefore encouraged to recognize the role of cities and local authorities in their national biodiversity strategies and action plans and to support the development of local biodiversity strategies and actions plans (SCBD, 2008). In 2010 the most elaborate document was accepted in a COP decision, by adopting a Plan of Action on Subnational Governments, Cities and Other Local Authorities for Biodiversity (CBD, 2010c). The mission of the Action Plan is to engage cities in achieving the objectives of the Convention and the implementation on the Strategic Plan for Biodiversity 2011-2020, including an indicative list of actions, as well as measures for monitoring and reporting. The Action Plan supports tools such as the Singapore Index on Cities' Biodiversity (CBI), which is a self-assessment tool to help cities evaluate and monitor the progress of their biodiversity conservation efforts. Under this index, 23 indicators were developed that measure native biodiversity, ecosystem services provided by biodiversity and governance and management of biodiversity. The Action Plan also mentions, albeit cautiously, funding opportunities for cities: Parties may identity funding oriented specifically towards biodiversity at the local level.

The Conference of Parties in 2010 asked the CBD Secretariat to prepare an assessment of the links and opportunities between urbanization and biodiversity. The Cities and Biodiversity Outlook is the first global analysis on the projected urbanization and the effects on biodiversity. This policy document was prepared for the eleventh meeting of the Parties in 2012 (SCBD, 2012). At COP 11 Parties were invited to develop guidelines and capacity-building initiatives to develop, enhance or adapt local biodiversity strategies and action plans. Parties, development organizations and other donors were invited to support initiatives by networks of local governments, such as the ICLEI local Action for Biodiversity Initiative. Parties were also encouraged to monitor and report on the contribution of their cities to reaching the Aichi Targets, in particular in their fifth national reports (see below, section 4) (CBD, 2012).

In 2014 the Conference of Parties strengthened their intentions to cooperate with local governments. Parties were invited to increase their efforts to enable, support and guide strategic and sustainable urbanization by working together with local governments for achieving the Aichi Targets. Parties were asked to incorporate biodiversity considerations into their urban, peri-urban, land-use and infrastructure planning, such as green infrastructure. The COP Decision also addressed 
local governments themselves by encouraging them to contribute to the implementation of the Biodiversity Strategic Plan 2011-2020 (CBD, 2014).

Whereas the Biodiversity Convention has recognized the importance of cities in the implementation of the Convention, also cities have acknowledged the role they can play in implementing the Biodiversity Convention, for instance by the Curibita Declaration on Cities and Biodiversity (2007), strengthened by the Second Curibita Declaration in 2010. At the City Biodiversity Summit in 2010 the Aichi/Nagoya Declaration on local authorities and biodiversity was accepted. These documents, although legally non-binding, all confirm the commitments of the signatories to contribute actively to the implementation of the Biodiversity Convention. In the Aichi/Nagoya Declaration, cities supported the Action Plan that was established by COP Decision IX/28.

\subsection{Ramsar Convention}

The Ramsar Convention on Wetlands of International Importance especially as Waterfowl Habitat does also not exclude wetlands in urban areas. The focus of the Convention was for a long time on wetlands in rural areas. The explicit attention for wetlands in urban environments is fairly recent and was formally recognized by Resolution X.27, adopted at the Conference of Parties in 2008 (Ramsar, 2008). The Resolution recognized that wetlands in urban and peri-urban environments can deliver many important ecosystem services to people, and that urban green and blue space is increasingly known to contribute to people's physical and mental health and well-being. Parties are therefore urged to pay attention to the importance of their wetlands in urban and peri-urban environments and to take appropriate measures to conserve and protect these wetlands. States should review the state of these environments and put in place schemes for their restoration and rehabilitation, so that they can deliver their full range of ecosystem services to people and biodiversity. In 2012, principles for planning and management of urban and peri-urban wetlands were established by Resolution XI.11 (Ramsar, 2012). Parties are urged to consider principles for policy development and implementation, and practical principles for wetland conservation and restoration. The appendix to the Resolution identifies key issues facing wetlands from pressures associated with urbanization, as well as a number of potential solutions to overcome these issues.

In 2015, a COP Resolution provided a voluntary Wetland City Accreditation framework, establishing criteria that a city must fulfil in order to get accreditation. The accreditation would encourage cities that are close to and depend on wetlands to establish a positive relationship with these wetlands through increased participation and awareness and consideration of wetlands in local planning and decision making (Ramsar, 2015). However, the accreditation does not confer any legal rights or legal obligations on the city or the Party to the Convention.

Although the recent attention for urban wetlands under the Ramsar framework is certainly recommendable, the regime falls short on specific technical guidelines for specific urban challenges such as fragmentation and urbanization of wetland watersheds (Hettiarachchi, 2015).

\subsection{Examples of regional instruments: The Bern Convention and EU law}

Also in regional environmental law, recent attention has been given to urban biodiversity and urban ecosystem services. Two examples are briefly discussed: The European Bern Convention and EU biodiversity laws and policy.

The Bern Convention on the Conservation of European Wildlife and Natural Habitat (1979), under the auspices of the Council of Europe, aims for the protection of wild flora and fauna in Europe.The 
Bern Convention is a regional biodiversity convention, with a broad scope and some interesting characteristics, including mostly strict obligations and an implementation mechanism (Jen, 1999; Diaz, 2010; Bowman et al., 2010; Trouwborst, 2011, 2016).

It served as the basis for the EU Nature Directives. Although the Convention as such does not explicitly address urban biodiversity in the Convention text, the Convention framework and institutional framework enable further interpretation and directions for the implementation of the Convention.The Standing Committee of the Bern Convention supported a Recommendation by the Congress of Local and Regional Authorities of the Council of Europe, on Biodiversity policies for urban areas (Congress of Local and Regional Authorities, 2008). In this Recommendation a number of recommendations were made to the Committee of Ministers of the Council of Europe, including that biodiversity should become a political priority in all Member States of the Council of Europe and the need to take account of the specificity of urban biodiversity in the struggle against biodiversity loss. The Standing Committee of the Bern Convention in its turn noted that urban biodiversity should be fully addressed in all biological diversity instruments, strategies and action plans. Issues relevant for urban biodiversity that are dealt with by the Standing Committee include invasive alien species, the conservation of wild species and the impacts of climate change (Standing Committee, 2008).

In the European Union, the Bern Convention has been implemented by the EU Nature Directives (Birds Directive, 2009; Habitats Directive, 1992). The Nature Directives provide a prime example of strong nature conservation legislation and are considered to be European nature's best hope (Born et al., 2015). The Nature Directives can apply to the protection and restoration of biodiversity in cities, especially in a strongly urbanized region as Europe. Although the Natura 2000 network, which is an ecological network of protected areas under the Directives can predominantly be found in rural areas, several cities include Natura 2000 sites (Sundseth \& Raeymaekers, 2006). Strict species provisions apply on the whole territory, thus including cities. Article 10 of the Habitats Directive obliges Member States to protect landscape features which are of major importance for wild fauna and flora and include linear elements (such as rivers with their banks or the traditional systems for marking field boundaries) or stepping stones (such as ponds or small woods). The EU policy on Green Infrastructure is of particular importance for urban biodiversity and ecosystem services. Green Infrastructure is defined as "a strategically planned network of natural and semi-natural areas with other environmental features designed and managed to deliver a wide range of ecosystem services. It incorporates green spaces (or blue if aquatic ecosystems are concerned) and other physical features in terrestrial (including coastal) and marine areas. On land, Gl is present in rural and urban settings." (European Commission, 2013).

All of the above mentioned international and regional environmental law instruments show the recent attention for urban biodiversity and the ecosystem services that urban biodiversity provides. On the one hand the importance of urban biodiversity is recognized, and on the other hand, the role of cities in the protection and restoration of biodiversity and the ecosystem services it provides, is recognized. The above mentioned initiatives are mostly taken in the form of legally non-binding COP decisions (under multilateral or regional Conventions) or policy (such as the EU Green Infrastructure policy). Most of these initiatives remain rather vague and do not set concrete targets for the protection and restoration of urban biodiversity and ecosystem services. Also, most initiatives rely on the implementation at the national level, through national or local biodiversity strategies and action plans. The next part explores the concrete international targets that have been set at the international level and that are relevant for urban biodiversity. It explores and discusses if and to what extent these targets have been translated for urban biodiversity and ecosystem services into national action plans. 


\section{International targets for protecting and restoring urban ecosystem services}

The scope of this article with regards to the international targets goes as far to elaborate on the Aichi Targets under the Biodiversity Convention, as the Aichi Targets solely focus on the protection of biodiversity, and they provide the most thorough and clear indication on urban biodiversity conservation as well as the national strategies and action plans. The United Nations Sustainable Development Goals also include targets on ensuring the sustainability of the cities (Goal 11) and restoring ecosystem services in order to halt biodiversity loss (Goal 15). Nevertheless, the Sustainable Development Goals are today at their infancy, and there is not yet a clear indication on urban biodiversity conservation. Neither there yet exists information on national implementation. Today, the discussion on urban areas focuses specifically on urban pollution -with a specific emphasis on air pollution- and urban-rural linkages (UN ECOSOC E/2016/75, 2016; UN A/70/472, 2015).

The Aichi Targets stem from the Strategic Plan of the Decision X/2 of the COP to the Convention on Biological Diversity (CBD). The Aichi Targets replace the unmet 2010 Biodiversity Targets (CBD, 2010b; SCBD, 2010; Tollefson et al., 2012). The overall mission of the Strategic Plan is to "take effective and urgent action to halt the loss of biodiversity in order to ensure that by 2020 ecosystems are resilient and continue to provide essential services, thereby securing the planet's variety of life, and contributing to human well-being and poverty eradication". The Strategic Plan consists of 5 strategic goals and 20 corresponding targets, the Aichi Targets. The targets related to ecosystem services are listed under strategic goal $D$.

The COP Decision $\mathrm{X} / 2$ stipulates that the implementation of these targets will be facilitated through national and subnational activities, i.e. via Parties' national biodiversity strategies and action plans (CBD, 2010b). The parties are to report the progress on national implementation of the Aichi Targets by means of their $5^{\text {th }}$ and $6^{\text {th }}$ national reports. Review of the midterm progress of these targets is facilitated through the $4^{\text {th }}$ edition of the Global Biodiversity Outlook (GBO).

Decision X/2 on the Aichi Targets is followed by the above mentioned Decision X/22 on the Plan of Action on Subnational Governments, Cities and Other Local Authorities for Biodiversity, which aims for better provision of ecosystem services for urban dwellers and incorporation of biodiversity concerns into urban planning and development by 2020 (CBD, 2010c). Pursuant to Decision X/22, the Cities Biodiversity Outlook (CBO) document has been published under the facilitation of the Secretariat of the Convention on Biological Diversity (SCBD). The report incorporates 10 key messages, many of which relate to the importance of urban ecosystem services restoration (CBD, 2012). It furthermore provides guidance and awareness on the importance of urban ecosystems restoration in order to contribute to climate change mitigation and adaptation. Within this context, the CBO acknowledges the importance of the restoration of urban ecosystem services in order to attain to Aichi Targets 14 and 15. The scope of this paper will therefore cover target 14 and 15 as these two targets are utmost related with urban ecosystem services.

\subsection{Target 14}

Aichi Target 14 aims to restore and safeguard essential ecosystem services that contribute to health, livelihoods and well-being by 2020 (CBD, 2010b). This is to be done by taking into account the needs of women, indigenous and local communities, and the poor and vulnerable. The CBO argues that 
maintaining urban ecosystem services can significantly improve human health and well-being (CBD, 2012). The Biodiversity Indicators Partnership goes one step further and states that health and wellbeing of communities are directly dependant on the local ecosystem services (Tyrrell et al., 2014). Consequently, ecosystem services restoration, taking into account the well-being of local communities and many vulnerable groups, will unavoidably require ecosystem services restoration in urban areas. Ecosystem services self-reliance could be one of the key aspects for urban sustainability ( $\mathrm{Wu}, 2014)$ as well as a sound solution for addressing target 14 .

\subsection{Target 15}

The objective of Aichi Target 15 includes contributing to climate change mitigation and adaptation by restoring at least $15 \%$ of the degraded ecosystems (CBD, 2010b). Considering what has been said in section 2 of this article on the contribution of cities to climate change via greenhouse gas emissions and the negative impacts of climate change on the cities and their dwellers, urban ecosystems restoration will be of crucial need. Previously mentioned examples from the practice further demonstrates that urban ecosystem services restoration can help to a great extent achieve the objectives of Target 15 (CBD, 2012).

\subsection{Assessment of implementation by reviewing the national reports}

Under Article 26 of the CBD, each Party to the Convention is to develop a national report on measures it has taken so as to implement the provisions of the Convention. These reports are accompanied by the national biodiversity strategy and action plans (NBSAP). During the fifth COP meeting, Parties agreed that the reports would be submitted in a periodical manner; once in every four years. National reports are indispensable instruments for the implementation of the Strategic Plan for Biodiversity 2011-2020 (CBD 2010b) as they indicate the progress towards the Aichi Targets undertaken by the COP. This is evident in the methodology used for the fourth edition of the GBO (GBO-4) regarding the progress towards the Aichi Targets as well as the evaluation of the mid-term outcomes on the succession of the Strategic Plan (SCBD, 2014). The GBO-4 bases its assessment on the fifth national reports. The deadline for submission of the latter decided under COP Decision X/10 was 31 March 2014 (CBD, 2010a). However, not all countries have submitted their reports by then. Therefore, the GBO-4 only includes reports from 64 Parties (SCBD, 2014). Until May 2016, 115 additional reports have been submitted by the Parties. This section will therefore assess the fifth national reports of 181 Parties to the CBD in order to evaluate the progress towards the achievement of Aichi Targets 14 and 15 . The section will specifically map the current state of progress of the Parties towards the restoration of urban ecosystem services (target 14) and ecosystem services restoration in urban areas for climate mitigation and adaptation (target 15). It should be noted however that due to language barrier, 8 out of 181 national reports could not be assessed.

Under their fifth individual national reports, nine Parties (China, Finland, Germany, Japan, Republic of Korea, Malta, Norway, Philippines, Singapore) both thoroughly acknowledge the value of urban ecosystem services and include urban ecosystem services in their restoration targets in correspondence to the Aichi Targets 14 and 15 respectively. These countries' reports focus, to a great extent, on the urban ecosystem services and urban restoration and conservation. Fourteen Parties (Algeria, Canada, Estonia, Haiti, India, Israel, Italy, Kenya, Lao, New Zealand, Poland, Solomon Islands, Sri Lanka, The United Kingdom) acknowledge the value of urban ecosystem services and include it in their national targets. Three of the Parties (Belgium, Denmark and Tunisia) acknowledge 
urban ecosystem services but do not include them in their targets. Eleven of the Parties (Australia, Austria, Brazil, Cameroon, Congo, Costa Rica, Guyana, Monaco, Niger, South Africa, Tonga) do not refer to the term urban ecosystem services but have several conservation and restoration targets in urban areas. Eighteen Parties (Azerbaijan, Benin, Chile, Djibouti, Bosnia Herzegovina, France, Iraq, Lebanon, Madagascar, Moldova, the Netherlands, Nigeria, Peru, Romania, Spain, Sweden, Switzerland and Tajikistan) somewhat acknowledge and refer to urban ecosystem services. The European Union, in its report, does not specifically acknowledge urban ecosystem services but often refers to green infrastructure, in general. Eight of the signatory Parties' fifth national reports could not be assessed due to the language barrier. The remaining 118 national reports neither refer to urban ecosystem services, nor do they have national targets on urban biodiversity conservation or restoration of urban ecosystem services. Nonetheless, a general consensus is present regarding the fact that urban sprawl is one of the biggest threats to biodiversity.

\subsection{Discussion}

This analysis demonstrates that the majority of the signatory Parties' national reports do not recognise biodiversity or ecosystem services in their urban settings. They furthermore do not have any strategic plans or targets for conservation of nature in urban areas. It should be noted that the COP Decision X/10 does not oblige the countries to develop a national target for each of the Aichi Targets, if they have already reached the threshold of some of the targets, or if a certain target is not relevant in the country context (CBD, 2010a). In this perspective, an assumption can be made on the fact that these 106 countries do not include such concerns either because they do not have high levels of urbanization or that they are already beyond the goal of Aichi Target 15 on restoration. Indonesia is one of the countries that do not have concerns on urban ecosystem services under their national report. Nevertheless, $53 \%$ of Indonesia's population is urbanized and this number will reach $70 \%$ by 2050 (UN, 2015). Likewise, the national report of Bangladesh does not include any input on urban ecosystem services or urban restoration and conservation; however, Bangladesh is one of the most rapidly urbanizing least developed countries with high pollution levels in urban areas (Marlier et al., 2016). These factors demonstrate that not all of these 106 countries have no essential need in urban ecosystem services or restoration in urban areas.

Since the reason for not including urban ecosystem services concerns in the majority of the Parties' national reports is not likely to be either of the abovementioned reasons, another reason may be that there are no concrete targets at the urban level. One of the objectives of the Subnational Action Plan is "to encourage and support local authorities to manage biodiversity sustainably, provide ecosystem services to citizens and incorporate biodiversity concerns into urban planning and development" (CBD, 2010c) by 2020. The mere fact that the majority of the Parties' lack of plans and strategies supporting such provision and incorporation leads to the conclusion that the overall efforts of the Subnational Governments have not resulted in achievement of these objectives within the global scale.

The solution for better implementation at the national level, can be facilitated through global efforts. Schewenius and colleagues (2014) argue that one-size-fits-all approach cannot be the solution for urban ecosystem services restoration. Nevertheless, they state that today many urban areas face global challenges such as climate change or sea-level rise. Action and policy guidelines under the $\mathrm{CBO}$ seem to support this argument, as it provides generalised guidelines for urban biodiversity conservation and ecosystem services restoration.

The verdict of the GBO-4 demonstrates that there is progress towards the targets 14 and 15 but at an insufficient rate (SCBD, 2014). Similarly, with regards to the urban ecosystem recognition and urban ecosystem services restoration, the assessment of this section shows that there is a 
developing understanding but nevertheless at an insufficient rate. Only one fourth of the countries recognise the concept of urban ecosystem services and the importance of urban restoration at variable levels.

Maxwell and colleagues (2015) argue that setting global targets can promote collaboration and global agreement in a complex area such as ecosystems and their services. However, without further agreeing on the details of these targets, specific methods and scope of implementation, they stipulate that there remains a high risk of not attaining to the intended goal. Implementation of the Aichi Targets depends on the States' individual actions (CBD, 2010b) and not on specific generalised methods. Lack of action on urban ecosystem services restoration from the majority of the States is highly likely to negatively affect the success of the Aichi Targets 14 and 15. In today's world in which the urban growth is rapidly expanding to the world's most biodiversity rich areas (Güneralp et al., 2013; Seto et al., 2012; Mcdonald et al., 2008), urban ecosystem services restoration could be one of the most efficient solutions to attain to these targets. Even though the COP Decision X/22 as well as the $\mathrm{CBO}$ strives to provide guidance and awareness on urban ecosystem services restoration in order to attain to the Aichi Targets, stronger legal implication rather than encouragement remains necessary for these targets to succeed.

\section{Conclusions}

This paper strived to demonstrate firstly the importance of biodiversity conservation in urban areas with regards to the delivery of ecosystem services, and therefore the importance of promoting ecosystem restoration in urban areas.

Secondly, the article reviewed and assessed the implementation of the international and regional legal instruments on biodiversity conservation. With regards to the international instruments, the authors argue that both the CBD and Ramsar Convention include urban areas within their scope for conservation. The CBD's COP decisions hold the key for implementation and they recognise the need to implement the CBD at the city level in order to attain to the Aichi Targets. The voluntary Wetland City Accreditation Network under the Ramsar Convention enhances the awareness on urban biodiversity, but it lacks legal rights or obligations. Furthermore, the Ramsar regime lacks technical guidance on urban biodiversity conservation and ecosystem restoration. Overall, most of the implementation relies on non-binding action plans and strategies.

At the regional level the authors note that the Bern Convention's Standing Committee stipulates that urban biodiversity should be addressed within biodiversity strategies and action plans. The EU Birds and Habitats Directives do not exclude the protection or restoration of biodiversity in urban areas, although most implementation in Member States has taken place in rural areas. Furthermore, the EU Green Infrastructure policy compliments on the restoration of urban ecosystems. Although the focus of these regional instruments has so far not been on urban biodiversity, they can play an important role in achieving the global commitments at the regional level, as the instruments discussed have stronger implementation mechanisms and stronger legal obligations than the global ones.

The Aichi Targets are one of the essential pillars when it comes to non-binding documents that relate to urban biodiversity conservation. The targets' implementation and success rely on the national strategies and action plans. An analysis of the national action plans indicates that the majority of the signatory countries do not have much say on urban biodiversity conservation or urban ecosystem restoration. In today's rapidly urbanized world where more than half of the global population lives in cities, action on urban biodiversity is crucial so as to attain to the Aichi Targets as well as to meet the objectives of the international and regional conventions on the protection of biodiversity and ecosystem services. 
The importance of urban biodiversity continues to be a priority under the $\mathrm{CBD}$, as is demonstrated in the draft decisions for the next CBD COP meeting in Cancun in December 2016 (CBD, 2016). Both the draft decisions on biodiversity and climate change, and on ecosystem restoration, explicitly address urban areas. Often, the language in those COP decisions is still rather promotional than obligatory (using words like "encouraging" and "promoting"). In spite of their soft language, the decisions are nevertheless at least a political commitment which can be further used at the regional and national level. It is doubtful that additional strong legal obligations will be agreed upon at the international level in the short term. It is feasible and essential however to have more concrete guidance in future COP decisions, such as the short-term action plan on ecosystem restoration, combined with stronger monitoring and feedback mechanisms for national efforts. Thus would the Global Biodiversity Outlook further establish its authority on implementation overview and the international targets' succession would then become more attainable. The authors acknowledge that pure voluntary commitments will not suffice to attain the international biodiversity targets. The role of regional and national instruments, based on the global commitments, can play a crucial role in this regard. Rather than working out new legal instruments at the regional level, existing binding instruments can be used, not only using them for protection of biodiversity in rural areas, but also in urban environments. The potential role of regional instruments such as Bern Convention and EU Directives regarding the protection and restoration of urban biodiversity need to be further explored.

\section{Acknowledgements}

The authors acknowledge the anonymous reviewers for their valuable comments on both the contents and structure of the paper.

JAH thanks the Natural Environment Research Council for support through Research Grant Number NE/J015067/1) "Fragments, Functions and Flows in Urban Ecosystem Services" (F3UES) as part of Biodiversity and Ecosystem Service Sustainability Programme.

\section{References}

- Alvey, A. A., 2006. Promoting and preserving biodiversity in the urban forest. Urban For. Urban Green. 5, 195-201. doi:10.1016/j.ufug.2006.09.003.

- Balvanera, P., Pfisterer, A.B., Buchmann, N., He, J.S., Nakashizuka, T., Raffaelli, D., Schmid, B., 2006. Quantifying the evidence for biodiversity effects on ecosystem functioning and services. Ecology Letters. 9, 1146-1156.

- Bern Convention, 1979. Convention on the Conservation of European Wildlife and Natural Habitat, Bern, 19 September 1979.

- Birds Directive, 2009. Directive 2009/147/EC of the European Parliament and of the Council of 30 November 2009 on the Conservation of Wild Birds, Official Journal L 20, 26 January 2010, replacing the original Birds Directive, Directive 79/409/EEG of 2 April 1979 on the Conservation of Wild Birds, Official Journal L 103, 25 April 1979.

- Born, C.-H., Cliquet, A., Schoukens, H., Misonne, D. \& Van Hoorick, G. (eds.), 2015. The Habitats Directive in its EU Environmental Law Context: European Nature's Best Hope?, Routledge.

- Bowman, M., Davies, P., Redgwell, C., 2010. Lyster's International Wildlife Law, Second Edition, Cambridge, pp. 297-345.

- Cardinale, B,J. Duffy, J.E., Gonzalez, A., Hooper, D.U., Perrings, C., Venail, P., Narwani, A., Mace, G.M., Tilman, D., Wardle, D.A. Kinzig, A.P. Daily, G.C., Loreau, M., Grace, J.B. 
Larigauderie, A., Srivastava, D.S., Naeem, S., 2012. Biodiversity loss and its impact on humanity. Nature. 486, 59-67. doi: 10.1038/nature11148.

- $\quad$ CBD, 1992. Convention on Biological Diversity, 5 June 1992.

- CBD, 2008. COP Decision IX/28. Promoting engagement of cities and local authorities.

- CBD, 2010a. COP-10 Decision X/10. National reporting: review of experience and proposals for the fifth national report. Report number: UNEP/CBD/COP/DEC/X/10.

- CBD, 2010b. COP-10 Decision X/2. Strategic Plan for Biodiversity 2011-2020. Report number: UNEP/CBD/COP/DEC/X/2.

- CBD, 2010c. COP-10 Decision X/22. Plan of Action on Subnational Governments, Cities and Other Local Authorities for Biodiversity.

- CBD, 2012. COP Decision XI/8. Engagement of other stakeholders, major groups and subnational authorities.

- CBD, 2014. COP Decision XII/9. Engagement with subnational and local governments.

- $\quad \mathrm{CBD}, 2013$. Draft decisions for the thirteenth meeting of the conference of the parties to the Convention on biological diversity, UNEP/CBD/COP/13/2, 25 July 2016.

- Chiesura, A., 2004. The role of urban parks for the sustainable city. Landsc. Urban Plan. 68, 129-138. doi:10.1016/j.landurbplan.2003.08.003.

- Cincotta, R.P., Wisnewski, J. \& Engelman, R., 2000. Human population in the biodiversity hotspots. Nature. 404, 990-992. doi:10.1038/35010105.

- Congress of Local and Regional Authorities, 2008. Recommendation 232, 2008. Biodiversity policies for urban areas.

- Costanza, R., de Groot, R., Sutton, P., van der Ploeg, S., Anderson, S.J., Kubiszewski, I., Farber, S., Turner, R.K., 2014. Changes in the global value of ecosystem services. Glob. Environ. Chang. 26, 152-158. doi:10.1016/j.gloenvcha.2014.04.002.

- European Commission, 2016. COP 21- Nature-Based Solutions for Climate Resilience - An EU Perspective; organised by IUCN, In Paris - European Commission. () https://ec.europa.eu/commission/2014-2019/vella/announcements/cop-21-nature-basedsolutions-climate-resilience-eu-prespective-organised-iucn-paris_en (accessed 1 July 2016).

- Diaz, C., 2010. The Bern Convention: 30 Years of Nature Conservation in Europe. RECIEL. 19 (2), 185-196.

- Dover, J.W., 2015. Green Infrastructure: Incorporating Plants and Enhancing Biodiversity in Buildings and Urban Environments. Earthscan/Routledge, 352.

- Elmqvist, T., Setälä, H., Handel, S.N., Van der Ploeg, S., Aronson, J., Blignaut, J.N., GómezBaggethun, E., Nowak, D.J., Kronenberg, J., De Groot, R., 2015. Benefits of restoring ecosystem services in urban areas. Current Opinion in Environmental Sustainability. 14, 101 $-108$.

- European Commission, 2013. Communication from the Commission to the European Parliament, the Council, the European Economic and Social Committee and the Committee of the Regions. Green Infrastructure (GI) - Enhancing Europe's Natural Capital (COM/2013/0249 final).

- European Parliamentary Research Service. 2016. Bridging the rural-urban divide: Ruralurban partnerships in the EU. EPRS |. PE 573.898.

- Gómez-Baggethun, E., and Barton, D.N., 2013. Classifying and valuing ecosystem services for urban planning. Ecological Economics. 86, 235-245.

- Grafius, D., Corstanje, R., Warren, P., Evans, K., Hancock, S., Harris, J., 2016. The Impact of Land Use/Land Cover Scale on Modelling Urban Ecosystem Services. Landscape Ecology. doi:10.1007/s10980-015-0337-7. 
- Grêt-Regamey, A., Weibel, B., Kienast, F., Rabe, S., Grazia, Z., 2015. A tiered approach for mapping ecosystem services. Ecosystem Services. 13, $16-27$.

- Güneralp, B., McDonald, R.I., Fragkias, M., Goodness, J., Marcotullio, P.J., Seto, K.C., 2013. Urbanization forecasts, effects on land use, biodiversity, and ecosystem services, in Elmqvist, T., Fragkias, M., Goodness, J., Güneralp, B., Marcotullio, P.J., McDonald, R.I., Parnell, S., Schewenius, M., et al. (eds.), Urbanization, biodiversity and ecosystem services: Challenges and opportunities, Dordrecht, Springer, pp. 437-452. doi:10.1007/ 978-94-007-7088-1.

- Haaland, C., Van den Bosch, C.K., 2015. Challenges and strategies for urban green-space planning in cities undergoing densification: A review. Urban Forestry and Urban Greening. $14,760-771$.

- Haase, D., et al., 2014. A Quantitative Review of Urban Ecosystem Service Assessment: Concepts, Models, and Implementation. Ambio. 43, 413 - 433.

- Habitats Directive, 1992, Directive 92/43/EEC of 21 May 1992 on the Conservation of Natural Habitats and Wild Fauna and Flora, Official Journal L 206, 22 July 1992.

- Henderson, S.P.B., Perkins, N.H., and Nelischer, M., 1998. Residential Lawn alternatives: A study of their distribution, form and structure. Landscape and Urban Planning. 42, 135 145.

- Hettiarachchi, M., Morrison, T.H., McAlpine, C., 2015. Forty-three years of Ramsar and urban wetlands. Global Environmental Change. 32, 57-66.

- Hooper, D.U., Chapin, F.S., Ewel, J.J., Hector, A., Inchausti, P., Lavorel, S., Lawton, J.H., Lodge, D.M., Loreau, M., Naeem, S. and Schmid, B., 2005. Effects of biodiversity on ecosystem functioning: a consensus of current knowledge. Ecological monographs, 75: 1,3-35.

- Ishii, H., Manabe, T., Ito, K., Fujita, N., Mianashi, A., Hashimoto, D. Et al., 2010. Integrating ecological and cultural values towards conservation and utilization of shrine/temple forests as urban green space in Japan. Landscape and Ecological Engineering. 6, 307 - 315.

- Jen, S., 1999. The Convention on the conservation of European wildlife and natural habitats (Bern, 1979): Procedures of application in practice. Journal of International Wildlife Law and Policy. 2:2, 224-238.

- Kabisch, N., Frantzeskaki, N., Pauleit, S., Naumann, S., Davis, M., Artmann, M., Haase, D., Knapp, S., Korn, H., Stadler, J., Zaunberger, K. and Bonn, A., 2016. Nature-based solutions to climate change mitigation and adaptation in urban areas: perspectives onindicators, knowledge gaps, barriers, and opportunities for action. Ecology and Society. 21: 2, 39. http://dx.doi.org/10.5751/ES-08373-210239.

- Kaye, J.P., Groffman, P.M., Grimm, N.B., Baker, L.A., Pouyat, R. V., 2006. A distinct urban biogeochemistry? Trends Ecol. Evol. 21, 192-199.

- Kowarik, I., 2011. Novel urban ecosystems, biodiversity, and conservation. Environmental Pollution. 159, $1974-1983$.

- Kühn, I., Brandl, R., Klotz, S., 2004. The flora of German cities is naturally species rich. Evol. Ecol. Res. 6, 749-764. doi:10.1109/JSEN.2009.2035730.

- Le Roux, D., Ilkin, K., Lindenmayer, D.B. Blanchard, W., Manning, A.D., Gibbons, P., 2014. Reduced availability of habitat structures in urban landscapes: Implications for policy and practice. Landscape and Urban Planning. 125, 57-64.

- Lindenmayer, D.B. et al., 2013. New policies for old trees: averting a global crisis in a keystone ecological structure. Conservation Letters. 7, 61-69.

- Lorenz, K., Lal, R., 2009. Biogeochemical C and N cycles in urban soils. Environ. Int. 35, 1-8. doi:10.1016/j.envint.2008.05.006.

- Luck, G.W., 2007. A review of the relationships between human population density and biodiversity. Biol. Rev. 82, 607-645. doi:10.1111/j.1469-185X.2007.00028.x.

- Luederitz, C., et al., 2015. A review of urban ecosystem services: six key challenges for future research. Ecosystem Services. 14, 98-112. 
- Macdonald, R.I., Kareiva, P., Forman, R.T.T., 2008. The implications of current and future urbanization for global protected areas and biodiversity conservation. Biological Conservation. 141, $1695-1703$.

- Marlier, M.E., Jina, A.S., Kinney, P.L., DeFries, R.S., 2016. Extreme Air Pollution in Global Megacities. Curr. Clim. Chang. Reports 15-27. doi:10.1007/s40641-016-0032-z.

- Martos, A., Pacheco-Torres, R., Ordóñez, J., Jadraque-Gago, E., 2016. Towards successful environmental performance of sustainable cities: Intervening sectors. A review. Renewable and Sustainable Energy Reviews. 57, 479- 495.

- Maxwell, S.L., Milner-Gulland, E.J., Jones, J.P.G., Knight, A.T., Bunnefeld, N., Nuno, A., Bal, P., Earle, S., Watson, J.E.M., Rhodes, J.R., 2015. Being smart about SMART environmental targets. Science. 347:6226, 1075-1076. doi:10.1126/science.aaa1451.

- Mcdonald, R.I., Kareiva, P., Forman, R.T.T., 2008. The implications of current and future urbanization for global protected areas and biodiversity conservation. Biol. Conserv. 141, 1695-1703. doi:10.1016/j.biocon.2008.04.025.

- McKinney, M.L., 2006. Urbanization as a major cause of biotic homogenization. Biological Conservation. 127, $247-260$.

- Millennium Ecosystem Assessment, 2005. Ecosystems and Human Well-Being: Synthesis.

- Pauchard, A., Aguayo, M., Pena, E., Urrutia, R., 2006. Multiple effects of urbanization on the biodiversity of developing countries: The case of a fast-growing metropolitan area (Concepcion, Chile). Biological Conservation. 127:3, 272 - 281. doi:10.1016/j.biocon.2005.05.015.

- Ramsar, 1971. Convention on Wetlands of International Importance especially as Waterfowl Habitat, Ramsar, 2 February 1971.

- Ramsar, 2008. Resolution X.27. Wetlands and urbanization.

- Salmond, J.A., Tadaki, M, Vardoulakis, S., Arbuthnott, K., Coutts, A., Demuzere, M., Dirks, K.N., Heaviside, C., Lim, S., Macintyre, H., McInnes, R.N., and Wheeler, B.W., 2016. Health and climate related ecosystem services provided by street trees in the urban environment. Environmental Health 15: 1, 36. doi 10.1186/s12940-016-0103-6

- SCBD, 2010a. COP-10 Decision X/10. National reporting: review of experience and proposals for the fifth national report. Report number: UNEP/CBD/COP/DEC/X/10.

- SCBD, 2010b. COP-10 Decision X/2. Strategic Plan for Biodiversity 2011-2020. Report number: UNEP/CBD/COP/DEC/X/2.

- SCBD, 2010c. COP-10 Decision X/22. Plan of Action on Subnational Governments, Cities and Other Local Authorities for Biodiversity.

- SCBD, 2010. Global Biodiversity Outlook 3., Journal of the American Podiatric Medical Association. doi:10.7547/0003-0538-104.3.A1.

- SCBD, 2012. Cities and Biodiversity Outlook: Action and Policy 16. doi:10.6084/m9.figshare.99889.

- SCBD, 2012. Cities and Biodiversity Outlook: Action and Policy 16. doi:10.6084/m9.figshare.99889.

- SCBD, 2014. Global Biodiversity Outlook 4. doi:10.1093/aje/kwq338.

- Schaffler, A., Swilling, M., 2013. Valuing green infrastructure in an urban environment under pressure - The Johannesburg case. Ecological Economics. 86, $246-257$.

- Schewenius, M., McPhearson, T., Elmqvist, T., 2014. Opportunities for increasing resilience and sustainability of urban social-ecological systems: Insights from the URBES and the cities and biodiversity outlook projects. Ambio. 43, 434-444. doi:10.1007/s13280-014-0505-z. 
- Seto, K.C., Güneralp, B., Hutyra, L.R., 2012. Global forecasts of urban expansion to 2030 and Sciences of the United States of America. 109:40, 16083-16088. doi:10.1073/ pnas.1211658109.

- Shanahan, D., Fuller, R.A., Bush, R., Lin, B.B., Gaston, K.J., 2015. The Health Benefits of Urban Nature: How Much Do We Need? BioScience. 65:5, 476 - 485. doi: 10.1093/biosci/biv032.

- Soga, M., Yamaura, Y., Aikoh, T., Shoji, Y., Kubo, T. Gaston, K.J., 2015. Reducing the extinction of experience: Association between urban form and recreational use of public greenspace. Landscape and Urban Planning. 143, 69 - 75.

- Stadtentwicklung.berlin.de, 2016. BAF-Biotope Area Factor / Senate Department for Urban Development and the Environment - Berlin.) http://www.stadtentwicklung.berlin.de/umwelt/landschaftsplanung/bff/en/recht.shtml (accessed 1 July 2016).

- Standing Committee, 2008. Comments of the Bureau of the Standing Committee on Recommendation 232 (2008) of the Congress of Local and Regional Authorities of the Council of Europe on "Biodiversity policies for urban areas".

- Szlavecz, K., Warren, P., Pickett, S., 2011. Biodiversity on the Urban Landscape, in: Cincotta, R.P., Gorenflo, L.J. (Eds.), Human Population: Its Influences on Biological Diversity, Ecological Studies 214. Springer-Verlag, Berlin, pp. 1-12. doi:10.1007/978-3-642-16707-2.

- Tan, P.Y., Wang, J., Sia, A., 2013. Perspectives on five decades of the urban greening of Singapore. Cities. 32, $24-32$.

- Tollefson, J., Gilbert, N., 2012. Earth summit: Rio report card. Nature. 486, 20-23. doi:10.1038/486020a.

- Trouwborst, A., 2011. Conserving European Biodiversity in a Changing Climate: The Bern Convention, the European Union Birds and Habitats Directives and the Adaptation of Nature to Climate Change. RECIEL. 1, 62-77.

- Trouwborst, A., 2016. Wilderness protection under the Bern Convention. The perspective of Europe's large carnivores, in: Bastmeijer, K. (Ed.), Wilderness Protection in Europe. The Role of International, European and National Law, Cambridge University Press, pp.160-176.

- Tyrrell, T., Bolt, K., Macdevette, M., Campbell-lendrum, D., 2010. Indicator (s) on the Health \& Well-being of Communities Directly Dependent on Local Ecosystems. Ecosystems. 1-29.

- United Nations, 2014. World Urbanization Prospects, the 2014 Revision. doi:10.4054/DemRes.2005.12.9.

- United Nations General Assembly, 2015. Sustainable development, Report of the Second Committee. A/70/472.

- United Nations Economic and Social Council, 2016. Progress towards the Sustainable Development Goals, Report of the Secretary General. E/2016/75. doi:10.1017/S0020818300006640.

- Van Den Berg, M., Wendel-Vos, W., Van Poppel, M., Kemper, H., Van Mechelen, W., Maas, J., 2015. Health benefits of green spaces in the living environment: A systematic review of epidemiological studies. Urban For. Urban Green. 14, 806-816. doi:10.1016/j.ufug.2015.07.008.

- Verschuuren, J., 2008. Ramsar soft law is not soft at all. Discussion of the 2007 decision by the Netherlands Crown on the Lac Ramsar site on the island of Bonaire, http://archive.ramsar.org/pdf/wurc/wurc verschuuren bonaire.pdf 
- Young, O.R., 2011. Effectiveness of international environmental regimes: existing knowledge, cutting-edge themes, and research strategies. Proc. Natl. Acad. Sci. U. S. A. 108, 19853-60. doi:10.1073/pnas.1111690108.

- Ziter, C., 2016. The biodiversity-ecosystem service relationship in urban areas: a quantitative review. Oikos, 125, $761-268$. doi: 10.1111/oik.02883. 


\begin{tabular}{|c|c|}
\hline Comment & Response \\
\hline \multicolumn{2}{|l|}{$\begin{array}{l}\text { Reviewer \#1: The authors poorly responded to some } \\
\text { recommendations such as: }\end{array}$} \\
\hline $\begin{array}{l}\text {-"Why is such a convention [the Bern one] a more binding one? } \\
\text { Which are the institutional, political, social or even economic } \\
\text { elements of context that could explain it? Furthering these issues } \\
\text { would consequently enrich the article and especially section } 3 \text { and } \\
4 " .\end{array}$ & $\begin{array}{l}\text { The general characteristics of the Berne Convention and its } \\
\text { strengths have been addressed in other publications. We have } \\
\text { included some more references. We have also briefly added some } \\
\text { elements explaining the strength of the Berne Convention. It is } \\
\text { however beyond the scope of this paper to deal with this is detail, } \\
\text { especially since the Berne Convention did not yet extensively deal } \\
\text { with urban ecosystem services. Both the Bern Convention and the } \\
\text { EU directives are merely given as a regional example, but the } \\
\text { overall focus of the article is a global one. }\end{array}$ \\
\hline $\begin{array}{l}\text { - "An in-depth and comprehensive critical assessment of the } \\
\text { 14th and 15th Aichi Targets would be interesting, especially } \\
\text { concerning the used indicators and both their relevance and their } \\
\text { efficiency". } \\
\text { Consequently, section } 3 \text { and } 4 \text { remain weak concerning the } \\
\text { political and institutional elements which could enlighten the } \\
\text { debates on the implementation of more binding instruments (in } \\
\text { order to enforce highlights } 3 \text { and 4). }\end{array}$ & $\begin{array}{l}\text { We have assessed the two targets specifically regarding their } \\
\text { relevance to the restoration of urban ecosystems. The political } \\
\text { and institutional elements related to overall implementation have } \\
\text { been addressed under Section } 3.1 \text {. Moreover, such elements } \\
\text { related to implementation of urban ecosystem restoration are } \\
\text { further addressed in detail under Sections } 4.1 ., 4.2 \text {., and } 4.4 \text {. } \\
\text { The reason why we did not assess the overall implementation of } \\
\text { these targets is because the scope of this paper does not cover } \\
\text { the assessment of overall implementation of targets } 14 \text { and } 15 \\
\text { but rather is specifically related to urban ecosystem services. The } \\
\text { paper does not aim to provide such an assessment as this would } \\
\text { broaden the scope and cause incoherence with the previous } \\
\text { sections as well as the general objective and message of the } \\
\text { paper. }\end{array}$ \\
\hline $\begin{array}{l}\text { Reviewer \#2: The authors have taken sufficiently into account the } \\
\text { reviewers comments. }\end{array}$ & \\
\hline
\end{tabular}




\begin{tabular}{|c|c|}
\hline e was adapted accor & \\
\hline $\begin{array}{l}\text { Reviewer \#3: Although there is improvement in including legal } \\
\text { aspects/analysis within the paper, the edition lacks emphasizing } \\
\text { them. The introduction spends most paragraphs on the } \\
\text { importance of urban ecosystem services' conservation, which is } \\
\text { not particularly covered elsewhere in the paper. }\end{array}$ & $\begin{array}{l}\text { The narrative of the paper is: } \\
\text { - Why biodiversity and ecosystem services are important, and } \\
\text { should be conserved or restored } \\
\text { - Why this is only patchily implemented at the moment } \\
\text { - What the various levels of legal protection are } \\
\text { We do however agree that this narrative is not sufficiently } \\
\text { explained in the introduction. We have amended the introduction } \\
\text { part accordingly. }\end{array}$ \\
\hline $\begin{array}{l}\text { Moreover, in terms of legal dimensions that represent most of the } \\
\text { paper's content, the introduction only mentions: "The next } \\
\text { sections will examine whether international law provides an } \\
\text { adequate legal basis to do so". It is important that the } \\
\text { introduction actually introduces what is going to be described in } \\
\text { the following sections and some general ideas on findings; it } \\
\text { should not include relevant information not covered elsewhere in } \\
\text { the paper. }\end{array}$ & $\begin{array}{l}\text { We deal with these aspects extensively in the findings section. } \\
\text { However, we have given a more detailed outline of the legal part } \\
\text { in the introduction (see also comment below). }\end{array}$ \\
\hline $\begin{array}{l}\text { For instance, the paper's contribution includes the monitoring of } \\
\text { AICHI Targets and content on the Ramsar Convention, but that is } \\
\text { not at all mentioned in the introduction. This is strange especially } \\
\text { because those topics are emphasized in the } \\
\text { conclusion. }\end{array}$ & See response above (and see comment below). \\
\hline $\begin{array}{l}\text { Most of the content of the current introduction (that is quite long) } \\
\text { might be added as another section covering the importance of } \\
\text { urban ecosystem services' conservation and research efforts as } \\
\text { background for the rest of the paper. }\end{array}$ & $\begin{array}{l}\text { We have indeed restructured the paper accordingly and included } \\
\text { a more general introduction, mostly explaining the purpose and } \\
\text { structure of the paper. A next section deals with the importance } \\
\text { of urban ecosystem services (the 'introduction' part in the } \\
\text { previous version of the paper). }\end{array}$ \\
\hline $\begin{array}{l}\text { 3. In addition, the use of spaces between words and after } \\
\text { punctuation needs revision }\end{array}$ & Don \\
\hline
\end{tabular}

